\title{
CD4 count improvement as result of enhanced wellbeing of HIV/AIDS patients
}

\author{
Alfred Said Sife' ${ }^{1}$ Tumaini Jonas Wapalila ${ }^{2}$, Maulilio John Kipanyula ${ }^{3^{*}}$ \\ 'Sokoine National Agricultural Library (SNAL), Sokoine University of Agriculture, PO. Box 3022 Chuo Kikuu, Morogoro, Tanzania \\ ${ }^{2}$ Morogoro Regional Commisioner's Office, Boma Road, P.O. Box 650 Boma Road, Morogoro, Tanzania \\ ${ }^{3}$ Department of Anatomy Histology and Cell Biology, College of Veterinary and Medical Sciences, Sokoine University of Agriculture, P.O.Box 3016, Morogoro - \\ Tanzania
}

\section{Article Info}

\section{Article Notes}

Received: January 03, 2017

Accepted: February 23, 2017

\section{*Correspondence:}

Maulilio John Kipanyula, Department of Anatomy Histology and Cell Biology, College of Veterinary and Medical

Sciences, Sokoine University of Agriculture, P.O.Box 3016,

Morogoro - Tanzania, E-mail: kipanyula@suanet.ac.tz

C 2017 Maulilio John Kipanyula. This article is distributed under the terms of the Creative Commons Attribution 4.0 International License.

\section{Keywords}

Wellbeing

Tunajali

Home based care

CD4

HIV

AIDS

\section{ABSTRACT}

The CD4 T-cell count is an important laboratory indicator of the immune status in patients with HIV/AIDS. It is used in decision making to determine when antiretroviral therapy and a need of prophylaxis for opportunistic infections should be initiated. This study was carried out to assess the contribution of donor funded projects to the wellbeing of people living with HIV/AIDS as measured by improvement of CD4 count. A total of 120 respondents were randomly selected from Morogoro urban and Kilombero district, Tanzania. Based on panel data, individual observations were made four times across time and there were a total of 480 observations. The home based care TUNAJALI project provided various interventions including medical care and psychological support with the purpose of improving the health status of people living with HIV/AIDS. The effect of home based care TUNAJALI services was the only predictor of health status of people living with HIV/AIDS that was measured as an improvement of CD4 count over time. The average CD4 count before, one year, two years of home based care, and during the study were: 193.86; 258.83 (25.1\%); 375.72 (31.2\%); 487.57 respectively. A positive relationship was observed between home based care services and well-being. The findings from the present study show that the home based care positively improved the well-being of HIV/AIDS patients in the studied population. Improved wellbeing also improved CD4 count in patients.

\section{Introduction}

The Acquired Immunodeficiency Syndrome (AIDS), caused by the Human Immunodeficiency Virus (HIV), constitutes one of the formidable challenges to human development ${ }^{1,2}$. It is a disease of the human immune system caused by infection with HIV which primarily infects cells such as Cluster of Differentiation $4 \mathrm{~T}$ helper cells $\left(\mathrm{CD}^{+} \mathrm{T}\right)$, macrophages and dendritic cells ${ }^{3}$. Two types of HIV have been reported and characterized - HIV-1 and HIV-2. HIV-1 was the first to be discovered and initially was referred to as LAV or HTLV-III. This strain is considered to be more virulent and more infective and responsible for majority of HIV infections globally. On the other hand, HIV-2 is largely confined in West Africa and it has lower infectivity ${ }^{4}$. HIV/AIDS has been in existence since 1981, and the number of people living with the diseases continues to grow. By the end of 2015, there were about 36.9 million people living with HIV globally, with 2.0 million new HIV infections occurring every year and 1.2 million HIV/AIDS-related annual deaths5. Sub-Saharan Africa (SSA) is the most affected region in the world having two thirds (25.8 million) of the global population living with HIV/AIDS ${ }^{6,7}$. 
In Tanzania, the first three cases of HIV were reported in 1983 in Kagera region and the epidemic had reached all regions in the country by the end of 1986 . In 2012, around 1.6 million people (about six percent of the country's population) were living with HIV in Tanzania ${ }^{8}$.

Along with other tests, the CD4 count which measures the number of CD4 $\mathrm{T}$ cells in the blood helps to tell how strong the immune system is and indicates the stage of HIV/AIDS and therefore guides treatment plans, and predicts the prognosis of the disease. While efforts to develop a vaccine and cure for HIV/AIDS are underway, to date efforts for mitigating its impacts depend largely on effective prevention, care and treatment strategies. Antiretroviral therapies (ARV), which can delay the disease progression, improve well-being and increase patient's CD4 count ${ }^{7,9}$. In high-income countries, the availability of ARV has helped to improve health outcomes and maximise well-being among large numbers of people living with HIV/ AIDS (PLWHA), thus transforming HIV/AIDS from a fatal disease to a manageable chronic illness. This is however not the case in poorer parts of the world, particularly subSaharan Africa, where the epidemic is most severe, due to partly limited or completely lack of access to ARVs. Keeping CD4 count high can reduce health complications from HIV/ AIDS and extend patient's life.

International efforts to combat HIV began in the first decade of the epidemic with the creation of the WHO's Global Programme on AIDS in 1987. In 1996, UNAIDS was formed to serve as the United Nations system's coordinating body and to help galvanize worldwide attention to AIDS. In 2000, targets to halt and reverse the spread of HIV by 2015 were established as part of the Millennium Development Goals (MDGs), and the World Bank launched its Multi-Country AIDS Program (MAP) ${ }^{10}$. Furthermore, the role played by the affected country governments and civil society is considered to be critical to the response. A number of donor funded programmes have been implemented to provide care and support services as a way of improving the well-being for people living with HIV/AIDS (PLWHA) in many African countries ${ }^{11,12}$.

This study was carried out to assess the contribution of donor funded projects to the wellbeing of people living with HIV/AIDS as measured by improvement of CD4 count due to home based care (HBC) and assistance from TUNAJALI project. The changes in CD4 count was strongly associated with improved wellbeing of PLWHA due to the assistance accrued from TUNAJALI project. Improved wellbeing remarkably correlated with improved CD4 count in patients.

\section{Methods}

\section{The Tunajali Project}

The TUNAJALI (“WE CARE") was a donor funded project involved with HBC interventions for PLWHA, among other activities in Tanzania. The project operated in five regions in Tanzania namely; Coast, Dodoma, Morogoro, Mwanza and Iringa. The HBC services were designed to increase the uptake of counselling and testing services, especially targeting people who are the least likely to attend facilities due to poor access and fear of discrimination. In addition the HBC TUNAJALI project provided various interventions including medical care and psychological support with the purpose of improving the health status of PLWHA.Through the TUNAJALI project, the designated health facilities and community organizations in these three regions were provided with technical, managerial, and financial assistance. The project was implemented by Family Health International (FHI) and Deloitte and supported by USAID.

Study design: This study was conducted in November 2012 in Morogoro region in Tanzania. Morogoro is among the few regions in which the HBC TUNAJALI project operates. The study population comprised of all PLWHA supported by TUNAJALI project in the region. TUNAJALI staff in Morogoro region were also included in the study population. The study sample was obtained through a three level multistage sampling. First, two districts namely Morogoro Municipality and Kilombero were purposively chosen because they had high infection rates of $6.9 \%$ and $4.9 \%$ respectively (MRC, 2011). Second, eight wards, four from each district were selected based on the number of PLWHA that were supported by the project. The chosen wards were Lumemo, Michenga, Ifakara and Kibaoni Wards in Kilombero District as well as Mazimbu, Mafiga, Kihonda and Mzinga wards in Morogoro Municipality. Finally, convenience sampling was used to obtain 15 respondents in each ward, making a total of 120 respondents. Based on panel data, individual observation was made across time, each observation was made four times, thus there were a total of 480 observations.

Data Collection: Primary data were collected through structured questionnaire. Time series and cross-sectional design were employed in which data were collected at a single point in time (cross-sectional) but each individual observation was made across time (panel data). Panel data were obtained through retrospective questions (crosssectional surveys by retrospective questions). Secondary data were obtained from various sources including TUNAJALI offices.

Data Analysis: Data were analysed using SPSS and STATA software. The following multiple regression model based on panel observations was employed in the analysis:

$\mathrm{Y}_{\mathrm{it}}=\alpha+\beta_{1} \mathrm{X}_{1 \mathrm{it}}+\beta_{2} \mathrm{X}_{2 \mathrm{i}}+\beta_{3} \mathrm{X}_{3 \mathrm{it}}+\mathrm{T}+\lambda_{\mathrm{t}} \ldots \ldots \ldots+\varepsilon_{\mathrm{it}}$

Where;

$\mathrm{Y}_{\mathrm{it}}=\mathrm{CD} 4$ counts or income of the $\mathrm{i}^{\mathrm{th}}$ individual observed in time $\mathrm{t}$ 
$\mathrm{X}_{1 \mathrm{it}}=$ The age of an individual $\mathrm{i}$ observed in time $\mathrm{t}$ measured in years.

$\mathrm{X}_{2 \mathrm{i}}=$ Sex of an individual - 1 if an individual is a male

$\mathrm{X}_{3 \mathrm{it}}=$ Marital status of an individual $\mathrm{i}$ observed in time $\mathrm{t}$

$\mathrm{T}=1,2,3$ (number of times an individual attend HBC TUNAJALI services)

$\lambda_{\mathrm{t}}=0$ if an individual CD 4 Counts or income was measured for the first time,

1 if measured after the first time.

Ethics Approval and Consent to Participate: Permission to carry out this study was granted by the Morogoro urban and Kilombero district executive directors. Ethics approval for the study was given by the Ethical Committee of the Sokoine University of Agriculture (SUA), Morogoro, Tanzania. The Vice-Chancellor of the SUA issued a research permit on behalf of the Tanzania Commission for Science and Technology (COSTECH) that permitted the study to be carried out. Prior to data collection, verbal consent was obtained from each study participant after the purpose and importance of the study was explained. The respondents were assured that they could withdraw from the study at any time.

\section{Results}

\section{Demographic characteristics}

Age, sex, marital status, and education level were analysed to provide a snapshot on the background of the respondents (Table 1). An analysis of the background was particularly important because some of the characteristics were associated with well-being of PLWHA. The majority $(69.2 \%)$ of the respondents were females. More than a half (56.7\%) of the respondents aged between 30 and 45 years old confirming the fact that generally HIV prevalence is high in socially, economically and sexually active age groups. Over a third (35.8\%) of the respondents were married and a quarter $(25.8 \%)$ of the respondents were single. The great majority $(86.7 \%)$ of the respondents had primary level of education. With regard to income generating activities, most $(57.9 \%)$ respondents were engaged in petty trading. Slightly over half $(51.7 \%)$ of the respondents had family sizes ranging from 4 to 6 persons.

\section{Activities Implemented by HBC TUNAJALI Project for the Well-Being of PLWHA}

Information about the activities implemented by TUNAJALI was gathered through key informant interview with the project coordinator and review of project documents. TUNAJALI implemented several activities to provide psychological, health care, economic and legal support. Medical support was one of the services provided by the TUNAJALI project. For instance, a great majority $(86.7 \%)$ of the respondents received medical support

\begin{tabular}{|c|c|c|}
\hline Category & Frequency & Percent \\
\hline $\begin{array}{l}\text { Age in years } \\
18-29 \\
30-45 \\
46 \text { and above }\end{array}$ & $\begin{array}{c}7 \\
69 \\
44\end{array}$ & $\begin{array}{c}5.8 \\
57.5 \\
36.7\end{array}$ \\
\hline $\begin{array}{l}\text { Sex } \\
\text { Male } \\
\text { Female }\end{array}$ & $\begin{array}{l}37 \\
83\end{array}$ & $\begin{array}{l}30.8 \\
69.2\end{array}$ \\
\hline $\begin{array}{l}\text { Marital status } \\
\text { Married } \\
\text { Divorced } \\
\text { Separated } \\
\text { Widow/widower } \\
\text { Single }\end{array}$ & $\begin{array}{c}43 \\
3 \\
20 \\
23 \\
31\end{array}$ & $\begin{array}{c}35.8 \\
2.5 \\
16.7 \\
19.2 \\
25.8\end{array}$ \\
\hline $\begin{array}{l}\text { Education level } \\
\text { Primary } \\
\text { Secondary } \\
\text { No formal education }\end{array}$ & $\begin{array}{c}104 \\
14 \\
2\end{array}$ & $\begin{array}{c}86.7 \\
11.7 \\
1.7\end{array}$ \\
\hline $\begin{array}{l}\text { Occupation } \\
\text { Petty trading } \\
\text { Crop production } \\
\text { Self employment } \\
\text { No employment } \\
\text { Petty trading and crop production } \\
\text { Crop production and self employ- } \\
\text { ment } \\
\text { Petty and livestock keeping }\end{array}$ & $\begin{array}{c}38 \\
30 \\
5 \\
8 \\
33 \\
4 \\
2\end{array}$ & $\begin{array}{c}31.7 \\
25.0 \\
4.2 \\
6.7 \\
27.5 \\
3.3 \\
1.7\end{array}$ \\
\hline $\begin{array}{l}\text { Family size } \\
1-3 \\
4-6 \\
\text { More than } 6\end{array}$ & $\begin{array}{l}38 \\
62 \\
20\end{array}$ & $\begin{array}{l}31.7 \\
51.7 \\
16.7\end{array}$ \\
\hline
\end{tabular}

Table 1: Background characteristics $(n=120)$.

through drugs found in HBC kits. All respondents received of psychological support as nearly two thirds (62.5\%) of the respondents were provided with home visiting and counselling as well as access to PLWHA groups to share experiences with colleagues about their HIV positive status. The rest $(37.5 \%)$ were provided only with home visits and counselling. Seventy percent (70\%) of the respondents were provided with material support in form of bed sheets, mosquito nets, soap and food supplements to assist them overcome economic challenges. Only a few (2.5\%) respondents received legal support in the form of will writing and access to advocates. With regard to socio-economic support, $42.5 \%$ of the respondents joined the Internal Saving and Lending groups (SILC/CODET) established by the project. Fourty percent (40\%) of respondents resumed their income generating activities as a result of improved health status (Table 2).

\section{CD4 Counts of PLWHA}

The CD4 count measures the number of CD4 cells in a sample of blood. Along with other tests, the CD4 count is an important index on how strong the immune system is and it is often used as an indicator of the stage of HIV/ AIDS. It guides treatment and predicts how the disease may progress. Therefore, maintaining the CD4 count high 


\begin{tabular}{|c|c|c|c|}
\hline \multicolumn{2}{|r|}{ Type of support } & Frequency & Percent \\
\hline \multirow{3}{*}{ Medical support offered } & Drugs found in HBC kits & 104 & 86.7 \\
\hline & Drugs in $\mathrm{HBC}$ kits and transport fare & 13 & 10.8 \\
\hline & Drugs in $\mathrm{HBC}$ kits and referral to hosp & 3 & 2.5 \\
\hline \multicolumn{2}{|l|}{ Total } & 120 & 100.0 \\
\hline \multirow[b]{2}{*}{ Psychological support offered } & Home visiting and counseling & 45 & 37.5 \\
\hline & Home visiting and counseling \& access to PLWHA groups & 75 & 62.5 \\
\hline \multicolumn{2}{|l|}{ Total } & 120 & 100.0 \\
\hline \multirow{4}{*}{ Socio-economic support } & Linking to other financial institutions & 4 & 3.3 \\
\hline & Internal saving and lending groups SILC/CODET & 51 & 42.5 \\
\hline & Improved health status and be able to engage in income generating activities & 48 & 40.0 \\
\hline & None & 17 & 14.2 \\
\hline \multicolumn{2}{|l|}{ Total } & 120 & 100.0 \\
\hline
\end{tabular}

Table 2: Support services offered by HBC TUNAJALI project

can reduce complications of the disease and extend life of PLWHA.

In order to study the changes in CD4 counts in PLWHA, respondents were asked about their CD4 counts before and after joining TUNAJALI project. Before joining the HBC TUNAJALI project the average CD4 count of the respondents was 193.86 and a year later, the average CD4 count improved to 258.83. Two years after joining the project the average CD4 count rose to 375.72 during this study, the average CD4 count of the respondents was 487.57. Change of CD4 count was obtained by comparing the counts before and after joining TUNAJALI services. A large proportion of PLWHA included in this study were on ARV therapy, however majority did not adhere to treatment regime until when $\mathrm{HBC}$ was introduced. The HBC TUNAJALI project intervention involved, provision of medical care and psychological support with the purpose of improving the health status of PLWHA. Furthermore the intervention resulted into adherence to medical prescriptions including ARVs. Improvement was measured in terms of improvement of health status and CD4 counts.

Furthermore TUNAJALI HBC project ensured that clients are enrolled as early as possible into care and treatment programmes. The implementation of HBC heavily relied upon volunteers and the impact of HBC was magnified by the provision of home care kits to help with immediate medical, hygienic, and nutritional needs. The kits include items such as bed nets, water purification tablets, micronutrients, and pain-relieving and other essential drugs. Other clients especially those residing far away from CTC were in addition supported with fare to access health facilities. The HBC volunteers also accompanied PLWHA during hospital visits. This strategy ensured consistency and bridged the gap between the hospital and other clinical services patients needed. During this study, the average CD4 count of the respondents was 487.57. The results presented here clearly show that the average CD4 of the respondents significantly increased as the client's years of receiving services from HBC TUNAJALI project increased. Based on these data the HBC TUNAJALI Project interventions are likely to have influenced positively to improve the health status of PLWHA.

\section{Contribution of HBC TUNAJALI Project to the Well- being of PLWHA}

Determining the contribution of project activities was achieved by using regression analysis of panel data. Panel data (also known as longitudinal or cross sectional timeseries data) is a dataset in which the behaviour of entities is observed across time. Panel data allow one to control for variables that cannot be observed or measured such as cultural factors or variables that change over time but not across entities. The pooled regression result as well as the fixed effects and random effects regression results are summarized in Table 3.

Pooled Ordinary Least Square (OLS) results presented in Table 3 acts as a preliminary model to show relationship between variables and the key assumption is that individual effects do not exist. The result from the pooled OLS can seldom be taken to be final as we did not check weather individual effect existed or not. With regard to the health status of PLWHA, regression was significant ( $\mathrm{p} \leq$ 0.05 ) and the eleven independent variables accounted for $38 \%$ (Adjusted $\mathrm{R}^{2}=0.381$ ) of variation in health status of PLWHA. The results also showed that three of the eleven independent variables (age, education level and TUNAJALI services) included in the analysis had significant ( $\mathrm{p} \leq 0.05$ ) regression coefficients and all the three variables showed positive regression coefficient. This implies that age, education level and TUNAJALI services effect had positive relationship with health status of PLWHA.

Fixed effect model assumes that something within the individual may impact or bias the predictor or outcome 
variables, and this should be controlled. Table 4 presents the fixed effect and random effect results. Fixed effect removes the effect of those time-invariant characteristics from the predictor variables and hence the predictors' net effect can be assessed. Random effect assumes that the variation across entities is random and uncorrelated with the predictor or independent variables included in the model. The dropped variables indicated in Table 4 are those time invariant characteristics which are removed in

\begin{tabular}{|l|c|c|c|}
\hline \multicolumn{1}{|c|}{ Variables } & Coefficient & Standard Error. & P>t \\
\hline Age & 1.959853 & 0.847346 & 0.021 \\
\hline Sex & -26.5401 & 16.93786 & 0.118 \\
\hline Marital status & -14.617 & 16.50175 & 0.376 \\
\hline Petty trading & 30.45882 & 18.64019 & 0.103 \\
\hline Livestock keeping & -51.8558 & 54.93699 & 0.346 \\
\hline Crop production & -30.0075 & 16.58108 & 0.071 \\
\hline Self employed & 26.73259 & 34.18807 & 0.435 \\
\hline Not employed & -45.1437 & 33.91958 & 0.184 \\
\hline Education & 10.23288 & 4.407189 & 0.021 \\
\hline Family size & 4.787611 & 10.92573 & 0.661 \\
\hline TUNAJALI effects & 98.03342 & 6.190135 & 0.00 \\
\hline cons & -59.2155 & 51.8801 & 0.254 \\
\hline F-statistic & 27.32 & & \\
\hline P-value & 0.000 & & \\
\hline Adjusted R & & \\
\hline Number of observations (N) & 480 & & \\
\hline
\end{tabular}

Table 3: Pooled Ordinary Least Square (OLS) result of HBC TUNAJALI project on Health status of PLWHA.

\begin{tabular}{|l|c|c|c|c|c|c|}
\hline & \multicolumn{3}{|c|}{ Fixed effect } & \multicolumn{3}{c|}{ Random effect } \\
\hline \multicolumn{1}{|c|}{ Var } & Coef. & Std. Err. & P>t & Coef. & Std. Err. & \multicolumn{1}{c|}{ P>z } \\
\hline Age & 19.4536 & 11.59907 & 0.094 & 2.113149 & 1.295322 & 0.103 \\
\hline Sex & (dropped) & & & -29.4302 & 26.46366 & 0.266 \\
\hline Ms & (dropped) & & & -13.8368 & 25.42019 & 0.586 \\
\hline Pt & (dropped) & & & 29.80815 & 28.6742 & 0.299 \\
\hline Live & (dropped) & & & -52.6725 & 84.50347 & 0.533 \\
\hline Cprod & (dropped) & & & -30.3167 & 25.50726 & 0.235 \\
\hline Semp & (dropped) & & & 26.77561 & 52.62043 & 0.611 \\
\hline Noemp & (dropped) & & & -45.7765 & 52.15854 & 0.38 \\
\hline Edu & (dropped) & & & 10.42311 & 6.780113 & 0.124 \\
\hline Fsize & (dropped) & & & 4.46966 & 16.85125 & 0.791 \\
\hline Tueff & 74.95214 & 15.9197 & 0.00 & 97.71149 & 4.962073 & 0.000 \\
\hline cons & -637.6324 & 428.0506 & 0.137 & -64.5515 & 76.99821 & 0.402 \\
\hline
\end{tabular}

Table 4: Fixed and random effects results of HBC TUNAJALI project on Health status of PLWHA. fixed effect model so as to determine predictors' net effect.

In order to choose Fixed Effect (F.E) and Random Effect (R.F), the Housman test was conducted. The Housman test accepts the null hypothesis of no systematic difference in coefficient between the F.E and R.E $(\mathrm{P}=0.322)$. Therefore, the random effect model was opted for and the result was discussed by random effect model. The results from the random effect model showed that attendance to TUNAJALI project was responsible for PLWHA health improvement. This was further verified by comparing the CD4 counts in the successive periods of joining the TUNAJALI project using a paired sample t-test. Table 5 indicates that in all four pairs of successive periods of joining the project, a preceding period had on average low level of CD4 counts compared to the next period, in each case p-value was equal to 0.000 .

Furthermore, slightly over half (51.7\%) of the respondents admitted that HBC TUNAJALI Project was responsible for their change from bedridden patients to the healthy persons able to do anything, rise of their CD4 as well as awareness about living positive and free from opportunistic infections (Table 6).

\section{Discussion}

The CD4 T-cell count (CD4 count) is an important tool and the major laboratory indicator of the immune status in patients with HIV/AIDS. It is therefore used in decision making to determine when antiretroviral (ARV) therapy initiation and the need for prophylaxis for opportunistic infections should be prescribed. The CD4 count response following ARV therapy and improved wellbeing varies widely among HIV/AIDs patients and a poor response represents a severely compromised immune system. The absolute CD4 count is a calculated value derived from total white blood cell (WBC) count and the percentage of total and CD4+ T lymphocytes. The count is an absolute number that may fluctuate in individuals or may be influenced by factors that may affect the total WBC count and lymphocyte percentages. In that context it is also the strongest predictor of subsequent disease progression and survival according to findings from clinical trials and cohort studies ${ }^{13,14}$.

Generally, the provision of medical support has been considered as an important factor for improving the wellbeing of PLWHA. Previous studies ${ }^{7,15}$ have also shown that the life of PLWHA depends on effective prevention,

\begin{tabular}{|c|c|c|c|c|c|}
\hline & & CD4 Mean & $\mathbf{t}$ & df & Sig. (2tailed) \\
\hline Pair 1 & $\begin{array}{l}\text { CD4 for the first time since joined HBC TUNAJALI - CD4 one year since joined HBC } \\
\text { TUNAJALI }\end{array}$ & $\begin{array}{l}\text { Before- } 193 \\
\text { One year-258 }\end{array}$ & -5.688 & 119 & 0.000 \\
\hline Pair 2 & CD4 one year since joined HBC TUNAJALI - CD4 two years since joined HBC TUNAJALI & $\begin{array}{l}\text { Before-258 } \\
\text { Two yrs-375 }\end{array}$ & -10.251 & 119 & 0.000 \\
\hline Pair 3 & CD4 two years since joined HBC TUNAJALI - current CD4 & $\begin{array}{l}\text { Before-375 } \\
\text { Current-487 }\end{array}$ & -9.614 & 119 & 0.000 \\
\hline
\end{tabular}

Table 5: Paired sample t-test result for CD4 count changes and HBC TUNAJALI services over time. 


\begin{tabular}{|l|c|c|}
\hline HBC TUNAJALI responsible to the Health & Frequency \\
status & Percent \\
\hline Rise of CD4 & 1 & 0.8 \\
\hline Aware of living positive & 4 & 3.3 \\
\hline Rise of CD4 and change from bed ridden & 2 & 1.7 \\
\hline Rise of CD4 and aware of living positive & 48 & 40.0 \\
\hline $\begin{array}{l}\text { Change from bed ridden \& aware of living } \\
\text { positive }\end{array}$ & 3 & 2.5 \\
\hline $\begin{array}{l}\text { Rise of CD4, change from bed ridden and } \\
\text { aware of living positive }\end{array}$ & 62 & 51.7 \\
\hline Total & 120 & 100.0 \\
\hline
\end{tabular}

Table 6: Effect of HBC TUNAJALI Services on Health status of PLWHA.

care and treatment strategies, including ARV, which can delay the disease progression, improve well-being and increase life expectancy. In this study the HBC TUNAJALI services effect was the only predictor of health status of PLWHA and was measured in terms of improvement of CD4 count. Previous studies have shown that an adequate CD4 response for most patients on therapy is defined as an increase in CD4 count in the range of 50 to 150 cells $/ \mathrm{mm}^{3}$ per year, generally with an accelerated response in the first 3 months of treatment ${ }^{14}$. However, this has never been the case when patients are prescribed with ARV alone without social wellbeing support services ${ }^{16,17}$. Consistent with previous studies we observed a sustained increase of CD4 counts over time, which to a large extent was attributed to improved wellbeing from the HBC TUNAJALI services. The positive regression coefficient implied that TUNAJALI services effect and health status of PLWHA were positively related. Increased attendance to TUNAJALI services led to improved health status and CD4 count of PLWHA. These findings were similar to the studies among HIV infected persons in high-income countries that documented a positive relationship between social support and health outcomes $^{18,19}$.

The HBC TUNAJALI intervention activities positively improved the health status and income of PLWHA in the studied population in Morogoro region. The project interventions enabled PLWHA to resume to their daily activities and engage in productive activities which concurrently improved their well-being. The main interventions implemented by HBC TUNAJALI to improve well-being of PLWHA included; health care support, psychological support to enable PLWHA to cope with their HIV positive status and thus enhanced the positive living attitude, socio-economic and legal support. Furthermore, the HBC TUNAJALI project also facilitated establishment of saving and Internal Lending Community services (SILC). The SILC provided capital to PLWHA to initiate income generating activities in form of soft loans. Certainly, the findings from this study indicated that respondent's sex, age, marital status, family size, occupation and education level did not significantly influence the health status of
PLWHA. According to Adedemeji ${ }^{10}$, psychological issues that dominate the lives of PLWHA impact heavily affect their well-being. Constant worry, stress and anxieties about their future can contribute to poor health outcomes and may become catalysts for adopting ill health-enhancing behaviors. It is for that reason that psychological support played an important role in enhancing well-being of PLWHA in the studied population.

Although a positive relationship between HBC TUNAJALI project intervention activities and well-being of PLWHA were realized in the present study, sustainability issues related to well-being of PLWHA was observed as one of the major constraint affecting PLWHA supported by the donor funded projects. Some of PLWHA showed overdependence to the HBC TUNAJALI support activities threatening their well-being beyond the project duration. Stigma from the community members following disclosure of HIV status and inefficient remuneration of volunteers for the activities also affected the delivery of HBC TUNAJALI services to PLWHA. It is conceivable that the model used by the HBC TUNAJALI project by establishing and engaging PLWHA in income generating activities, can be used as a showcase to prepare PLWHA to sustain their well-being once donor funded supports reached an end. Furthermore, despite the constraints revealed in this study, it is evident that if well implemented, Donor Funded Projects are likely to improve the well-being of PLWHA.

Study Limitations: This study had several limitations. It was not possible to follow trends over a short period of time because data were collected at a single point in time, thus making it difficult to measure changes in the population. Also, convenient sampling may not have represented the entire population. The study might also suffer from recall bias, social desirability recall, and self-report bias. However, some measures were taken to reduce recall by asking few questions that required recall.

\section{Conclusion}

HIV/AIDS has caused immense human sufferings by affecting nutrition, livelihoods and well-being of individuals, households and affected communities at large. Several donor funded projects have to been instrumental to provide care and support services to improve the wellbeing for PLWHA. The findings from the present study showed that the HBC TUNAJALI Project positively improved the well-being of PLWHA in the studied population in Morogoro Region. Improved wellbeing also improved CD4 count in patients. Considering a large number of PLWHA in the Morogoro and other regions in Tanzania more civil society organizations, government institutions and private sectors should be engaged in provision of care and support services to PLWHA. 


\section{Acknowledgements}

This study was funded by Sokoine University of Agriculture.Technical support from TUNAJALI Project is highly appreciated.

\section{Abbreviations}

ARV : Antiretroviral

CD4+ T: Cluster of Differentiation 4 T helper cells

FHI : Family Health International

HBC : Home Based Care

HIV/AIDS : Human Immunodeficiency Virus/Acquired Immune Deficiency Syndrome

PLWHA : People Living with HIV/AIDS

TACAIDS : Tanzania Commission for AIDS

UNAIDS: Joint United Nations Programme on HIV/AIDS

USAID : United States Agency for International Development

WHO: World Health Organization

\section{Authors' contributions}

MJK carried out the study design, participated in data analysis and drafted the manuscript. ASS participated in the design of the study and drafted the manuscript. TJW conceived of the study, and participated in its design and coordination and helped to draft the manuscript. All authors read and approved the final manuscript.

\section{References}

1. Hosegood V, McGrath N. The impact of adult mortality on household dissolution and migration in rural South Africa. AIDS J. 2004; 18(11): $1585-1590$.

2. Lamptey P, Johnson J, Khan M. The Global Challenge of HIV and AIDS. Popul Bull. 2006; 61(1): $4-6$.

3. Alimonti JB, Ball TB, Fowke KR. Mechanisms of CD4+T lymphocyte cell death in human immunodeficiency virus infection and AIDS. J Gen Virol. 2003; 84(7): 1649 - 1661.

4. Gilbert PB, McKeague IW, Eisen G, et al. Comparison of HIV-1 and HIV2 infectivity from a prospective cohort study in Senegal. Stat Med. 2003; 22(4): $573-593$.
5. Saag MS, Schooley RT. Antiretroviral Chemotherapy. Curr Clin Top Infect Dis. 1998; 18: 154 - 179.

6. Alimonti JB, Ball TB, Fowke KR. Mechanisms of CD4+T lymphocyte cell death in human immunodeficiency virus infection and AIDS. J Gen Virol. 2003; 84(7): 1649 - 1661.

7. Deeks SG, Smith M, Holodniy M et al. HIV-1 Protease Inhibitors A review for clinicians. JAMA. 1997; 277(2): 145 - 153.

8. Saag MS, Schooley RT. Antiretroviral Chemotherapy. Curr Clin Top Infect Dis. 1998; 18: 154 - 179.

9. United Nations Joint Program on HIV/AIDS (UNAIDS). WorldAIDSDay, 2015. http://www.unaids.org/sites/default/files/media_asset/20150901_FactSheet_2015_en.pdf

10. United Nations Joint Program on HIV/AIDS (UNAIDS).Getting to Zero. http://www.unaids.org/sites/default/files/en/media/unaids/ contentassets/documents/unaidspublication/2010/JC2034_ UNAIDS_Strategy_en.pdf Retrieved on 15/02/2016.

11. United Nations Joint Program on HIV/AIDS (UNAIDS).World AIDS Day. [http://www.unaids.org/documents/20101123_Glob alReport_ em.pdf] site visited on 15/1/2016.

12. Adedemeji AA, Alawode AO, Odutolu O. Impact of care and social support on well-being among people living with HIV/AIDS in Nigeria. Iranian J Publ Health. 2010; 39(2): 30 - 38.

13. Schonnesson LN. Psychological and existential issues and quality of life in people living with HIV infection. J AIDS Care.2002; 14(3): 399 -404 .

14. Mellors JW, Muñoz A, Giorgi JV, et al. Plasma viral load and CD4+ lymphocytes as prognostic markers of HIV-1 infection. Ann Intern Med. 1997;126 (12):946-954.

15. Egger M, May M, Chêne G, et al. ART Cohort Collaboration. Prognosis of HIV-1-infected patients starting highly active antiretroviral therapy: A collaborative analysis of prospective studies. Lancet. 2002; 360(9327): 119-129.

16. Kaufmann GR, Perrin L, Pantaleo G, et al. CD4 T-lymphocyte recovery in individuals with advanced HIV-1 infection receiving potent antiretroviral therapy for 4 years: The Swiss HIV Cohort Study. Arch Intern Med. 2003; 163(18): 2187-2195.

17. Burgoyne R, Renwick R. Social support and quality of life over time among adults living with HIV in the HAART era. Soc Sci Med. 2004; 58(7): $1353-1366$.

18. Sowellet RL, Seals BF, Moneyham L, et al. Quality of life in HV-infected women in the south-eastern United States. J. AIDS Care. 1997; 9(5): $501-512$.

19. Azétsop J, Diop BA. Access to antiretroviral treatment issues of wellbeing and public health governance in Chad: what justifies the limited success of the universal access policy Philosophy Ethics and Humanities in Medicine. PEHM. 2013; 8: 8. doi:10.1186/1747-5341-8-8. 